\title{
Top Executives' Pay For Long-Run Performance And Corporate Governance
}

\author{
Ji-Young Ahn, Ewha Womans University, South Korea
}

\begin{abstract}
This study examines the possibility that the quality of corporate governance has effects on the dynamic relationship between CEO compensation and firm performance. Building on the dynamic view of CEO pay and firm performance and corporate governance literature, we find that firms with weak corporate governance are more likely to provide high powered long-run incentives to CEOs, indicating CEO incentive contracts can be replaced by the role of external corporate control when the external control mechanism is not functioning effectively from the optimal contracting view. Overall, the findings imply that firm's governance mechanism can generate cross-sectional variations in CEO long-term incentive contracts.
\end{abstract}

Keywords: Blockholders; CEO Compensation; Long-Term Performance; Dynamic Agency View

\section{INTRODUCTION}

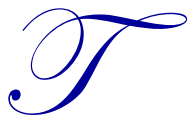

he long-term dynamic nature of CEO pay and performance has been limited in prior empirical literature) despite its theoretical and practical implications (e.g., Joskow and Rose, 1994). Researchers have exclusively emphasized estimating the contemporaneous pay-performance relationship (Antle and Smith, 1986). Very few studies have attempted to explore the existence of multi-period dynamic compensation structures. For example, Ahn (2015) empirically presented comprehensive evidence on the existence of a dynamic performance-pay relationship for CEOs. It shows that firms do target a long-run CEO compensation structure that is based on both current and past firm performance. In addition, the typical firm converges toward its long-run target compensation profiles at a rate of nearly $100 \%$ in a year, indicating that firms take steps to offset deviation from their optimal CEO pay (Ahn, 2015).

Building on Boschen and Smith (1995)'s dynamic nature of the CEO pay for performance relationship, this study attempts to uncover the cross-sectional variation in the dynamic relationship between CEO compensation and firm performance. One potential contingency for generating the variations in CEO compensation contracts is the quality of a firm's external corporate governance, serving a monitoring role in mitigating the agency problem between shareholders and managers (Hartzell and Starks, 2003). The optimal contract view maintains that information asymmetry generates the links between CEO incentive systems and firm value, predicting the existence of an optimal target CEO pay (Holmstrom, 1999; Wang, 1997). However, recent evidence on CEOs' opportunistic behaviors such as option back-dating and gaming their pay system negates the view of CEO compensation as optimal incentive contracts and that poor governance exacerbate such relationship (Garvey and Milbourn, 2006; Heron and Lie, 2007; Lie, 2005). As noted by Bebchuk and Fried (2003) in the following quote, compensation arrangements are often likely to be shaped by managerial influence, which leads to departure from the optimal target in directions favorable to executives.

"... market forces are not sufficiently strong and fine-tuned to assure optimal contracting outcomes... the constraints they(markets) impose are far from tight and permit substantial deviations from optimal contracting." (Bebchuk and Fried, 2003: p.74).

In brief, we explore the possibility that the quality of corporate governance moderate the dynamic relationship between CEO compensation and firm performance. Specifically, we test the concern that strong pay for "long-run" performance is raised in importance when external monitoring is weak. From the optimal view, pay that is strongly linked to long-run past performance is particularly pronounced in firms with weak external governance such that one 
mechanism (incentive compensation) may compensate for the other (monitoring) to better align with the long-term interests of shareholders. This is because firms with weak external corporate governance require commitment to long-run incentives for CEOs in order to prevent the CEO from engaging in short-term oriented actions, which in turn leads to implement a strong pay for "long-run" performance to bolster weak investor protections.

\section{THEORETICAL BACKGROUND AND HYPOTHESES}

The key idea behind the dynamic long-run relationship of CEO pay to firm performance is straightforward. In a dynamic agency model, CEO compensation can be characterized as the sum of a fixed level of compensation plus the compensation associated with current and past performance (Boschen \& Smith, 1995; Wang, 1997; Ahn, 2015). That is, the firm provides the CEO an incentive composed of current performance-based pay and a series of future expected compensations based on a history of firm's past performance. By linking contemporaneous pay to multiple periods of performance increases firm efficiency in attenuating effects of incomplete information about the top executives' actions and efforts (Wang, 1997; Holmstrom, 1999). In practice, top executives are indeed involved in multi-year long-term relationships with their firms, and one should examine the dynamic relationship between compensation and performance to find the complete pay-performance relationship (Boschen and Smith, 1995). In this setting, Ahn (2015) empirically show that realized future CEO pay levels should be affected by current and future performance.

Greater efforts have been devoted to examining alternative explanations and criteria for how CEO compensation is set. Two competing theories emerge. On the one hand, firms are optimizing with regard to CEO pay level in a way that maximizes the net expected economic value to shareholders as discussed in Demsetz and Lehn (1985). For instance, Fama (1980) posits that labor market discipline decreases agency problems with CEOs. They know that any opportunistic behavior will be penalized by a downward revision of the human capital value. In contrast, managerial power theorists criticized that optimal contracting approach imposes strict assumption that in setting executive compensation, directors take an adversarial position against CEOs and that the board is viewed as serving shareholder interests exclusively and bargaining with management in an arm's length way (Bebchuk et al, 2002), while managerial power view see these as not strong enough to follow optimal contracting model. Although both managerial power approach and agency theory has in common in explaining the executive compensation in that there is a agency problem such that the firm has well-diversified shareholders. But they take the recognition in different directions.

Managerial power theorists, Bebchuk et al. (2002) particularly focus on two preconditions that might generate CEO compensation that are optimal for shareholders. First mechanism is that the board operating at arm's length, determines the compensation structure that maximizes shareholder value. The optimal contracting view believe that the board has an important role in the process of setting CEO pay serving shareholder interests in this setting and bargaining with top management in an arm's length way (Bebchuk et al., 2002). The board has a full discretion to change the executive compensation on a certain periodic basis. The directors of large U.S public companies typically have established compensation committees that they delegate such responsibility to. Core et al. (1999) recognized the limitations of this assumption, but the full force has not been generally paid attention to the executive compensation literature (e.g., Bebchuk et al., 2002; Murphy, 2013).

Second, although the board behaves under the influence of top management, executives are limited by market forces such as large investors that own at least $5 \%$ of the outstanding shares of the firm. (blockholder, thereafter) and institutional investor to determine the compensation that best serves shareholder interests. Additionally, shareholders can use their rights within corporate law to block pay arrangements that are not best for shareholders. This may lead to force executives to adopt arrangements that maximize shareholder value. Again, managerial power view sees above-mentioned mechanisms not being strong enough to follow optimal contracting model (Shliefer and Vishny, 1997).

There is large evidence that the presence of a large shareholder (or blockholder) is important. When blockholder does not have a controlling position, its monitoring can decrease the excess pay (Bebchuk et al., 2002). Kole and Lehn (1997) examined the extent to which monitoring and incentive alignment of CEO compensation and influence patterns of various determinants on CEO pay is strongly related to ownership distribution in the firm. They use data 
which include the information of $175 \mathrm{CEO}$ in manufacturing industry and find evidence that the level of monitoring and incentive alignment is greater in owner-controlled with $5 \%$ of external shareholder- it is called "blockholder" than management-controlled firms. In the owner-controlled firms, there is more influence over CEO pay by major shareholders and board of directors while the CEO pay influence is isolated from major shareholders and boards. They suggest that a behavioral approach (managerial power theory) shed lights on the process to determine CEO pay.

One interesting study by Bertrand and Mullainathan (2001) suggest that the absence of shareholder owning more than $5 \%$ of the shares is related to significant deviation from optimal contracting. In the first section of their study, they examine companies with and without a large shareholder to examine if there is a difference in the extent to which CEOs are rewarded for changes in firm performance beyond their control- they call this "luck". The results indicate that CEOs in firms lacking large external shareholders seemed to receive more luck-based pay. The results show that an additional large shareholder on the board decreases pay for luck by approximately 30 percent.

Their results indicate that both views hold some way; firms with weak governance are consistent with the predictions of managerial power view, while firms with strong governance fit the predictions of the optimal contracting view. Large shareholders are particularly important as CEO stays longer with the firm, fitting the idea that unconstrained CEOs can entrench themselves over time. Additionally, Bertrand and Mullainathan (2000) suggest that firms with good quality of corporate governance charges CEOs more for options they were granted because options contain a gift component since CEO does nothing when they have value from the intrinsic volatility of the stock. Thus, firms with better governance features are better charge their CEOs and better able to remove this gift by cutting the other components of pay (cash and bonus).

Some studies have also suggested that a firm's control mechanism, especially the existence of active monitoring, can generate cross-sectional variations in CEO compensation contracts (e.g., Fama and Jensen, 1983). Included is the existence of large outside block-shareholders and shareholder protection. Scholars have theoretically addressed the substitution relationship between internal control such as compensation contracts and external control mechanisms, including outside block-shareholders and shareholder protection (e.g., Fama and Jensen, 1983). That is, the importance of managerial incentive contracts as internal governance is particularly pronounced when external monitoring (or control) is ineffective and costly (e.g., Beatty and Zajac, 1994). Thus, incentive compensation that is strongly tied to the firm performance is therefore appropriate when there is weak monitoring. It is concluded that the desired level of CEO incentive is contingent on the quality of a firm's external corporate governance because of a needed interaction (i.e., substitution) between the monitoring of top executives and incentive compensation (Beatty and Zajac, 1994).

The comprehensive survey by Graham, Harvey and Rajgopal (2005) of over 400 executives on their corporate financial decisions points at the temporal orientation of institutional owners. It finds that lack of institutional owners or block-holders induces a greater short-term CEO orientation; it may encourage CEO actions that bolster speculation and short-term myopic performance. This is because weak shareholder rights or absence of large outside block-holders might shield managers from outside monitoring, thereby encouraging the executives to boost "easily observable" short-term performance at the expense of long-run firm fundamental value (Stein, 1988). For instance, according to Graham, Harvey and Rajgopal (2005)'s survey, $80 \%$ of respondents report that in poorly governed firms, executives are more likely to be spurred by speculation in stock markets and take on short-term actions like earning manipulations by decreasing discretionary expenditure on R\&D, advertising and maintenance, for example, and even delaying profitable new projects and capital expenditures to boost short-term stock prices (Bolton and Dewatripont, 2005). Consequently, firms with weak external corporate governance are more likely to have difficulty in raising external funds in the long-term from outside investors unless they provide supplementary investor protection (Stein, 1988). Therefore, a certain form of intervention may be required to prevent CEOs' short-term orientation and to make a better alignment with the long-term interests of shareholders.

We have argued that weak monitoring induces CEOs' short-run oriented behaviors such as earnings manipulation that could potentially cost interests of shareholders. It is expected that CEO incentive contracts can be determined by institutional investors and replaced by the role of external corporate control when the external control mechanism is not functioning effectively. Combining these arguments, we posit that firms with weak external corporate 
governance require commitment to long-run incentives for CEOs in order to prevent the CEO from engaging in short-term oriented actions, which in turn leads to implement a strong pay for "long-run" performance. This leads to the competing following hypotheses:

Hypothesis 1a: The relationship between current pay and past long-run performance will be stronger in the firms with weak external corporate governance.

Hypothesis 1b: The relationship between current pay and past long-run performance will be stronger in the firms with strong external corporate governance.

\section{METHODS}

\subsection{Sample}

The sample construction is almost identical with Ahn (2015) except the fact that we included corporate governance measures from IRRC. The governance measure, Gompers $\mathrm{G}$ is obtained from the Investor Responsibility Research Center (IRRC) that publishes listings of corporate provisions for individual firms in Corporate Takeover Defenses (Gompers et al., 2001). These data are derived from different public sources including corporate bylaws and charters, proxy statements, annual reports, as well as $10-\mathrm{K}$ and 10-Q. The IRRC population covers most of the value-weighted market including NYSE, AMEX, and NASDAQ. We first constructed a sample from all CEOs included in the Executive Compustat (ExecuComp) and merged the sample with firm characteristics from the Compustat Industrial Annual data for the time period of 1992 to 2003. The ExecuComp data includes information on the compensation for the top executives of all the firms in the S\&P 500, S\&P Midcap 400, and S\&P SmallCap 600 as disclosed in the proxy statements. The data include information on cash compensation such as bonus and salary, the value of granted stock options, and restricted stocks in the current year. We exclude financial firms and utilities, since corporate governance of these regulated industries may reflect special factors (Murphy, 1999). Scholars have argued that in regulated industries, managerial discretion decreases as does the sensitivity of firm value to the quality of managerial decisions (Kole and Lehn, 1997; Ahn, 2015). We also exclude any firm with fewer than two consecutive years of data since empirical model includes lagged variables. These exclusions result in complete information for 7,193 observations, which include 1,980 CEOs.

\subsection{Measures}

Dependent variable. The Total Direct Compensation (hereafter, TDC) for the CEO is a dependent variable for the hypotheses. Total direct compensation is the total compensation for the individual year, comprised of the following: salary, bonus, total value of restricted stock granted, total value of stock options granted, long-term incentive payouts, and other miscellaneous items (TDC1 from ExecuComp). We used the modified Black-Scholes model when determining the value of stock options.

Independent variables. To capture the dynamic feature of CEO compensation, we used TDC $(\mathrm{t}-1)$, measured by the past year's total direct compensation for a given CEO. The measure of firm performance used in this study is the change in shareholder wealth as used in the Jensen and Murphy (1990). The change in shareholder wealth at year $t$ is defined as the rate of return realized by shareholders, multiplied by the beginning-of-period market value of the firm. To assess the dynamics of the pay-for-performance relationship, we include current, one-, two-, and three-year lags in firm performance in the model.

Two different proxies for external corporate governance are used. Gompers, Ishii, and Metrick (2001) constructed the governance index (hereafter, G-index) as the number of restrictions on shareholder rights. The index was constructed by adding one point for every provision that restricts shareholder rights (i.e., increases managerial power). The IRRC tracks 22 charter provisions, bylaw provisions, and other firm-level rules plus coverage under six state takeover laws; duplication between firm-level provisions and state laws yields 24 unique provisions. Examples are 'tactics for delaying hostile bidders;' 'voting rights'; 'director/officer protection'; 'other takeover defenses'; and 'state laws' (Gompers et al., 2001). Thus, the G-index is the sum of one point for the existence of each provision. A higher G-index implies weak governance in that there are more restrictions on shareholder rights and the manager 
has more discretion and is shielded against takeover threats. For strong restrictions, shareholders are less likely to engage in active monitoring.

Additionally, we measure outside shareholder control by using outside block-holder ownership provided by Dlugosz et al. (2006). Investors with more than or equal to $5 \%$ of the total stock ownership are considered to be block shareholders. If the block-holders are not officers, directors, affiliated entity, or ESOP employees, such blockholders are classified as "outside" block-holders and presumed to be in the best position to monitor management.

Control variables. The control variables include the firm characteristics, such as size (Baker, Jensen, and Murphy, 1988) and growth opportunity (Smith and Watts, 1992; Harvey and Shrieve, 2001) and risk (Aggarwal and Samwick, 1999). The measures of firm size are sales and market capitalization. Market-to-book ratio is included to control for growth opportunities market, measured by the market value of assets divided by the book value of the assets. CEO tenure is controlled for any effect it might have on the total compensation. To control for firm risk, past five-year volatility of monthly stock returns is used. We also CEO fixed effects to control for CEOs' unobserved heterogeneity. Finally, we include year fixed effects to control for any temporal year effects that might influence the results.

\subsection{Empirical Specification}

We estimate dynamic panel fixed-effect regression models whose dependent variable is total pay level, and one-year lagged total pay level is included as an explanatory variable. It is worth noting that we estimate the size of the effect of previous pay level, thereby avoiding the potential downward bias against finding the effects of past firm performance (Anderson and Hsiao, 1981). Similar to the recent empirical study, we attempt to minimize the statistical bias due to the correlation between unobserved CEO heterogeneity and the lagged total pay level. To do so, we use dynamic panel regression models introduced by Arellano and Bond (1991). In our empirical specification, we retest whether compensation level depends on both current and past long-run firm performance drawing upon the dynamic agency perspective; and (2) whether there is an interaction between firm performance and external corporate governance on CEO pay.

The typical CEO $t$ compensation measure is total direct compensation that is the sum of salary, bonus, other annual compensations, the total value of restricted stock granted, the total value of stock options granted (using the BlackScholes formula), long-term incentive payouts, and all other total compensations. The model incorporates the possibility that target compensation levels might differ across firms or over time by specifying a target CEO pay level of the form

$$
\begin{aligned}
T D C_{i, t}^{*}= & \beta_{1} R_{i, t}+\beta_{2} R_{i, t-1}+\ldots+\beta_{p} R_{i, t-p+1}+\beta_{c} X^{c}{ }_{i, t} \\
& +\beta_{d} G_{i, t}+\beta_{e} R_{i, t-p+1} \times G_{i, t}
\end{aligned}
$$

where $T D C^{*}{ }_{i, t}$ is a desired total direct compensation level for $\mathrm{CEO}_{i}$ at $t, R_{i, t-j}$

$j=1, \ldots, p$ is $j$ year lagged firm performance, $X^{c}{ }_{i, t}$ is a vector of firm characteristics related to optimal CEO pay

level, where $\beta=\left\{\begin{array}{lllllllllll}\beta_{1} & \beta_{2} & \ldots & \beta_{d} & \beta_{e}\end{array}\right\}$ is a coefficient vector and $X_{i, t}=\left\{\begin{array}{llllll}R_{i, t} & R_{i, t-1} & \ldots & R_{i, t-p+1} & X^{c}{ }_{i, t}\end{array}\right\}^{\prime}, G_{i, t}$ is Gompers $\mathrm{G}$ or block-holder ownership, our corporate governance measure. 


\section{EMPIRICAL RESULTS}

Descriptive statistics and correlation coefficients for all variables are reported in Table 1.

Table 1. Means, Standard Deviations, and Correlations of All Variables

\begin{tabular}{|c|c|c|c|c|c|c|c|c|c|c|}
\hline Variable & Mean & s.d. & 1 & 2 & 3 & 4 & 5 & 6 & 7 & 8 \\
\hline $\begin{array}{l}\text { 1. Total Direct } \\
\text { Compensation }^{\mathrm{a}}\end{array}$ & 4,098 & 12,100 & & & & & & & & \\
\hline $\begin{array}{l}\text { 2. Current Performance }{ }^{a} \\
\text { (Change in Shareholder } \\
\left.\text { Wealth }_{t}\right)\end{array}$ & 505 & 7,478 & 0.042 & & & & & & & \\
\hline $\begin{array}{l}\text { 3. Cumulative Past 2-year } \\
\text { Performance }^{\mathrm{a}}\end{array}$ & 844 & 9,358 & 0.133 & -0.081 & & & & & & \\
\hline 4. CEO Tenure (years) & 7.75 & 7.60 & -0.014 & -0.005 & -0.008 & & & & & \\
\hline 5. Firm Size ${ }^{\mathrm{a}}$ & 3,841 & 11,295 & 0.163 & 0.139 & 0.175 & -0.063 & & & & \\
\hline $\begin{array}{l}\text { 6. Risk (Stock return } \\
\text { volatility) }\end{array}$ & 0.45 & 0.24 & 0.046 & -0.061 & -0.086 & -0.058 & -0.165 & & & \\
\hline 7. Market to Book Ratio & 2.51 & 12.11 & -0.008 & 0.038 & -0.004 & -0.013 & -0.040 & 0.056 & & \\
\hline $\begin{array}{l}\text { 8. Governance Index } \\
\text { (Gompers G) }\end{array}$ & 9.22 & 2.71 & -0.002 & -0.002 & -0.001 & -0.104 & -0.018 & -0.226 & -0.091 & \\
\hline $\begin{array}{l}\text { 9. Outside Blockholder } \\
\text { Ownership (\%) }\end{array}$ & 17.00 & 14.00 & -0.072 & -0.078 & -0.174 & -0.076 & -0.195 & 0.142 & 0.096 & -0.082 \\
\hline
\end{tabular}

Note. $\mathrm{n}=7,193$ (sometimes fewer because of missing observations)

${ }^{a}$ The variable is measured in $\$ 1,000$ units.

All correlations above $|.03|$ are significant at the .05 level.

Table 2 reports the results of estimating the fixed-effect dynamic panel regression models to assess the impact of interaction between firm performance and external corporate governance on CEO pay. Column (1) presents the payperformance sensitivity using Arellano and Bond (1991) in order to control for the bias in fixed-effect dynamic panel. We sort our sample into two groups according to G-index. The median number of restrictions on shareholder rights is 9. Columns (1) and (2) in Table 2 present the estimates pay-performance relationship using lower G-index (i.e., $\mathrm{G}<9$ ) and higher $\mathrm{G}$-index (i.e., $\mathrm{G}>=9$ ) groups respectively. Consistent with the results in the previous section, both current and past firm performances are positively associated with total CEO pay (TDCt). However, the effect of contemporaneous performance for firms with strong shareholder rights shown in column (1) is larger than its counterpart for firms with weak shareholder rights. However, the results regarding the effect of long-term past firm performance are quite opposite: the coefficient of past stock performance for firms with weak shareholder rights is about twice as great as one for strong shareholder rights. 
Table 2. External Corporate Governance and Pay-Performance Relationship (t-statistics in parentheses)

\begin{tabular}{|c|c|c|c|}
\hline \multirow{2}{*}{ Variable } & \multicolumn{3}{|c|}{ Dependent Variable: Total Direct Compensation (TDC) } \\
\hline & $(1)^{\mathrm{a}}$ & $(2)^{b}$ & $(3)^{\mathrm{c}}$ \\
\hline Total Direct Compensation $(\mathrm{TDC})_{\mathrm{t}-1}$ & $\begin{array}{l}0.101^{*} \\
(1.93)\end{array}$ & $\begin{array}{l}-0.051 \\
(-1.40)\end{array}$ & $\begin{array}{l}-0.065^{* *} \\
(-2.17)\end{array}$ \\
\hline $\begin{array}{l}\text { Current Performance } \\
\left.\text { (Change in Shareholder Wealth }(\$ 1,000)_{t}\right)\end{array}$ & $\begin{array}{l}0.204 * * \\
(2.52)\end{array}$ & $\begin{array}{l}0.091 * * \\
(2.38)\end{array}$ & $\begin{array}{l}0.154 * * * \\
(5.34)\end{array}$ \\
\hline $\begin{array}{l}\text { Cumulative Past two-year Performance } \\
\text { (Change in Shareholder Wealth from year t-3 to t-1) }\end{array}$ & $\begin{array}{l}0.165^{* *} \\
(2.00)\end{array}$ & $\begin{array}{l}0.313^{* * *} \\
(6.75)\end{array}$ & $\begin{array}{l}0.175^{* * *} \\
(5.00)\end{array}$ \\
\hline Outsider Block-holder Ownership ${ }_{t-1}$ & & & $\begin{array}{r}2533.879 \\
(0.05)\end{array}$ \\
\hline Current Performance $\cdot$ Outsider Block-holder Ownership & & & $\begin{array}{c}-0.005 \\
(-0.73)\end{array}$ \\
\hline $\begin{array}{l}\text { Cumulative Past two-year Performance } \cdot \text { Outsider Block- } \\
\text { holder Ownership }\end{array}$ & & & $\begin{array}{l}-0.018 * * * \\
(-2.67)\end{array}$ \\
\hline CEO tenure $(\text { years })_{t-1}$ & $\begin{array}{l}-1.58 \mathrm{e}+04 \\
(-0.16)\end{array}$ & $\begin{array}{l}1.96 \mathrm{e}+06 \\
(0.32)\end{array}$ & $\begin{array}{r}-137.452 \\
(-0.00)\end{array}$ \\
\hline Firm Size $_{t-1}$ & $\begin{array}{r}-302.901 \\
(-0.44)\end{array}$ & $\begin{array}{r}251.137 \\
(1.27)\end{array}$ & $\begin{array}{c}-0.215 \\
(-0.00)\end{array}$ \\
\hline Stock Return Volatility $\mathrm{t}-1$ & $\begin{array}{r}-3098.661 \\
(-1.45)\end{array}$ & $\begin{array}{r}23.963 \\
(0.03)\end{array}$ & $\begin{array}{c}-3477.788^{* * * *} \\
(-3.43)\end{array}$ \\
\hline Market to book ratio $(1 \%) \mathrm{t}-1$ & $\begin{array}{r}-1219.448 \\
(-0.55)\end{array}$ & $\begin{array}{c}12755.954^{* * * *} \\
(6.80)\end{array}$ & $\begin{array}{r}1075.910 \\
(0.54)\end{array}$ \\
\hline Year-fixed effects & Yes & Yes & Yes \\
\hline CEO-fixed effects & Yes & Yes & Yes \\
\hline $\mathrm{N}^{\mathrm{a}}$ & 864 & 719 & 1,481 \\
\hline
\end{tabular}

$* \mathrm{p}<0.1 * * \mathrm{p}<0.05,{ }^{* * *} \mathrm{p}<0.01$, per two-tailed tests

Note: $(1)^{\mathrm{a}}$ represents estimates using lower G-index sample $(\mathrm{n}=864)$

$(2)^{b}$ represent estimates using higher G-index sample $(\mathrm{n}=719)$

$(3)^{c}$ represent estimates using whole sample with information on outsider block-holder ownership $(n=1,481)$

For a robustness check, we also examine the interaction effect of block-holder ownership on CEO total pay using the information of outside block-holder ownership as a proxy for the existence of external corporate governance and long-run firm stock performance. Column (3) presents the results from estimating the CEO fixed effect dynamic panel using outside block-holder ownership. We introduce interactions between the outside block-holder ownership and current year and previous two-year stock performances. This result of current stock performance is somewhat different from the results using Dlugosz, Fahlenbrach, Gompers, and Metrick's (2006) G-index. Although the payfor-current performance is statistically significant, we find no statistically significant evidence that the interaction between the contemporaneous stock performance and outside block-holder ownership explains CEO pay level. However, the qualitative results for the pay-for-"past" long-term performance is statistically and economically significant and robust: the coefficient of the previous two year stock performance is greater than one on the current stock performance and, more importantly, the interaction term between outside block-holder ownership and past stock performance significantly explains the CEO total pay level and the effect is negative. Overall, the results here support Hypothesis 1a that firms with weak external corporate governance tend to commit to long-run incentives, thereby bolstering weak investor protections.

\section{CONCLUSIONS}

Previous studies have argued that long-term components are an important part of performance-based compensation arrangements for top executives (Murphy, 2013). Thus, recent empirical efforts to strengthen the pay-performance sensitivity that focus both contemporaneous and dynamic long-run relation may be effective since the market has preferred longer-term incentive structures (Boschen and Smith, 1995; Ahn, 2015). In addition, studies have argued that firm's governance mechanism can generate cross-sectional variations in CEO compensation contracts (e.g., Murphy, 2013). Combined two arguments, the aim of the study is to explore the possibility that the quality of corporate governance moderates the dynamic relationship between CEO compensation and firm performance. 
The results of this study show that corporate governance, specifically, firm's external monitoring proxied as institutional owners or block-holders is an important part of dynamic performance-based compensation arrangements. Put another way, lack of institutional owners or block-holders induces a greater short-term CEO orientation. This is because weak shareholder rights or absence of large outside block-holders might shield managers from outside monitoring, thereby encouraging the executives to boost "easily observable" short-term performance at the expense of long-run firm fundamental value. In such setting, a certain form of institutional arrangements may be required to prevent CEOs' short-term orientation and to make a better alignment with the long-term interests of shareholders (Zingale, 1998). We test the possibility that firms with weak external corporate governance require commitment to long-run incentives for CEOs in order to prevent the CEO from engaging in short-term oriented actions, which in turn leads to implement a strong pay for "long-run" performance.

This paper presents the first comprehensive evidence on its moderating effect of the quality of firm's external governance building on the existence of a dynamic performance-pay relationship for CEOs. The results show that firms with weak corporate governance are more likely to provide high powered long-run incentives to CEOs. Evidence implies that CEO incentive contracts can be determined by institutional investors and replaced by the role of external corporate control when the external control mechanism is not functioning effectively. This is consistent with the theoretical claim that organizations take positive steps to bolster weak investor protections from the optimal contracting view (Jensen and Murphy, 1990).

\section{ACKNOWLEDGEMENT}

This work was supported by the National Research Foundation of Korea Grant funded by the Korean Government (NRF-2013S1A5A8024732)

\section{AUTHOR BIOGRAPHY}

Ji-Young Ahn is an associate professor of Ewha Womans University, 52 Ewhayeodae-gil, Seodaemun-gu, Seoul 120-750, South Korea. E-mail: jy-ahn@ewha.ac.kr

\section{REFERENCES}

Aggarwal, R., \& Samwick, A. (1999). The other side of the trade-off: the impact of risk on executive compensation. Journal of Political Economy, 107, 65-105.

Ahn, J. (2015). CEO pay for long-run performance: A dynamic view. Journal of Applied Business Research, 31(1), $317-329$.

Anderson, T., \& Hsiao, C. (1981). Estimation of dynamic models with error components. Journal of the American Statistical Association, 76, 598-606.

Antle, R., \& Smith, A. (1985). Measuring executive compensation methods and an application. Journal of Accounting Research, 23 (Spring), 296-325.

Arellano, M., \& Bond, S. (1991). Some tests of specification in panel data: Monte Carlo evidence and an application to employment equations. Review of Economic Studies, 58, 227-297.

Beatty, R. \& Zajac, E. (1994). Managerial Incentives, Monitoring, and Risk Bearing: A study of executive compensation, ownership, and board structure in initial public offerings, Administrative Science Quarterly 39, 313-335.

Bebchuk, L., \& Fried, J. (2003). Executive compensation as an agency problem. Journal of Economic Perspective, 17, 71-92.

Bertrand, M., \& Mullainathan, S. (2001). Are CEOs rewarded for luck? The ones without principals are. Quarterly Journal of Economics, 116(3), 901-932.

Bolton, P., \& Dewatripont, M. (2005). Contract Theory. MIT Press, Cambridge, MA.

Boschen, J., \& Smith, K. (1995). You can pay me now and you can pay me later: the dynamic response of executive compensation to firm performance. Journal of Business, 68, 577-608.

Core, J., \& Guay, W. (2001). Stock option plans for nonexecutive employees. Journal of Financial Economics, 61, $253-87$.

Dlugosz, J., Fahlenbrach, R., Gompers, R., \& Metrick A. (2006). Large blocks of stock: Prevalence, size, and measurement, Journal of Corporate Finance 12, 594- 618.

Fama, E. (1980). Agency Problems and the Theory of the Firm. Journal of Political Economy, 88, 288-307.

Fama, E. \& Jensen, M. (1983). Agency Problems and Residual Claims, Journal of Law and Economics 26, 327-49.

Garvey, G., \& Milbourn, T. (2006). Asymmetric benchmarking in compensation: Executives are rewarded for good luck but not penalized for bad. Journal of Financial Economics, 82, 197-225.

Gompers, W., Ishii, J., \& Metrick, A. (2001). Corporate governance and equity prices, Quarterly Journal of Economics 118, 107155. 
Graham, J., Harvey, C., \& Rajgopal, S. (2005). The economic implications of corporate financial reporting, Journal of Accounting and Economics 40, 3-73.

Hartzell, J. C., \& Starks, L. (2003). Institutional investors and executive compensation, Journal of Finance, 58(6), 2351-2375.

Harvey, K., \& Shrieve, R. (2001). Executive compensation structure and corporate governance choice. Journal of Financial Research, 24, 495-512.

Heron, A., \& Lie E., 2007, Does backdating explain the stock price pattern around executive stock option grants? Journal of Financial Economics 83, 271-295

Holmstrom, B. (1999). Managerial Incentives Problems: A Dynamic Perspective. Review of Economic Studies, 66, $169-182$.

Jensen, M., \& Murphy, K. (1990). Performance pay and top-management incentives. Journal of Political Economy, 98, $225-64$.

Joskow, P., \& Rose, N. (1994). CEO pay and Firm Performance: Dynamics, Asymmetries, and Alternative Performance Measures. NBER Working Paper W.4976. Cambridge, MA.

Kole, S., \& Lehn K. (1997). Deregulation, the evolution of corporate governance structure, and survival. American Economic Review, 87, 421-425.

Murphy, K. (1999). Executive Compensation. In O. Ashenfelter \& D.Card (ed.), Handbook of Labor Economics, vol.3. Amsterdam: North Holland.

Murphy, K. (2013). Executive compensation: where we are and how we got there, Handbook of Economics and Finance, Elsevier, North Holland.

Shleifer, A., \& Vishny, R. (1997). A survey of corporate governance. Journal of Finance, 52 (2), 737-84.

Smith, M., \& Watts, R. (1992). The investment opportunity set and corporate financing, dividend, and financing policies. Journal of Financial Economics, 32, 262-292.

Wang, C. (1997). Incentives, CEO compensation, and shareholder wealth: a dynamic agency model. Journal of Economic Theory, 76, 72-105.

Stein, J. (1988). Takeover threats and managerial myopia, Journal of Political Economy 96, 61-80.

Zingales, L. (1998). Corporate governance. In P. Newman, ed., The New Palgrave Dictionary of Economics and the Law, New York: Stockton Press. 


\section{NOTES}

